\title{
Zalecenia dotyczące leczenia chorych na raka podstawnokomórkowego i na raka kolczystokomórkowego przygotowane przez Sekcję Onkologiczną Polskiego Towarzystwa Dermatologicznego i sekcję Akademia Czerniaka Polskiego Towarzystwa Chirurgii Onkologicznej
}

\author{
Witold Owczarek ${ }^{1}$, Piotr Rutkowski ${ }^{2}$, Monika Słowińska ${ }^{3}$, Wojciech Wysocki ${ }^{4}$, \\ Marta Sołtysiak ${ }^{1}$, Zbigniew I. Nowecki ${ }^{2}$, Aleksandra Lesiak ${ }^{5}$, Krzysztof Herman ${ }^{4}$, \\ Rafał Czajkowski ${ }^{6}$, Lidia Rudnicka ${ }^{7}$, Arkadiusz Jeziorski ${ }^{8}$
}

Rak podstawnokomórkowy (BCC — basal cell carcinoma) oraz rak kolczystokomórkowy (SCC — squamous cell carcinoma) są najczęściej występującymi nowotworami złośliwymi występującymi u osób rasy kaukaskiej. Pomimo że rzadko prowadzą do powstawania przerzutów i zgonu chorego, to stanowią jednak bardzo istotny problem kliniczny, ponieważ charakteryzują się naciekaniem i niszczeniem sąsiadujących tkanek i struktur, co sprawia, że stają się powodem poważnych defektów estetycznych i znacząco upośledzają jakość życia chorych. U pacjentów w trakcie przewlekłej immunosupresji lub z genetyczną predyspozycją mogą mieć jednak agresywny i prowadzący do śmierci przebieg. Z tego powodu Sekcja Onkologiczna Polskiego Towarzystwa Dermatologicznego oraz sekcja Akademia Czerniaka Polskiego Towarzystwa Chirurgii Onkologicznej, na podstawie aktualnych wytycznych europejskich, rekomendacji amerykańskich National Comprehensive Cancer Network (wersja 1.2015) oraz interwencyjnych recenzji publikacji opracowanych przez Cochrane Skin Group, podjęła próbę usystematyzowania zasad postępowania diagnostyczno-terapeutycznego oraz ustalenia jednorodnych zasad prewencji pierwotnej i wtórnej u pacjentów z podejrzeniem/ /rozpoznaniem raka podstawnokomórkowego lub kolczystokomórkowego. W pracy przedstawiono aktualne zalecenia dotyczące rozpoznania i leczenia raków skóry, uwzględniając korzyści oraz problemy z nim związane, a także wytyczne monitorowania pacjentów po terapii.

\footnotetext{
${ }^{1}$ Wojskowy Instytut Medyczny

Centralny Szpital Kliniczny MON w Warszawie

${ }^{2}$ Centrum Onkologii — Instytut im. M. Skłodowskiej-Curie w Warszawie

${ }^{3}$ Centralny Szpital Kliniczny MSW w Warszawie

${ }^{4}$ Centrum Onkologii — Instytut im. M. Skłodowskiej-Curie

Oddział w Krakowie

${ }^{5}$ Klinika Dermatologii i Wenerologii

Uniwersytet Medyczny w Łodzi

${ }^{6}$ Szpital Uniwersytecki Nr 1 im. dr. A. Jurasza w Bydgoszczy

${ }^{7}$ Szpital Kliniczny im. Dzieciątka Jezus

Warszawski Uniwersytet Medyczny w Warszawie

${ }^{8}$ Wojewódzki Szpital Specjalistyczny im. Kopernika

Uniwersytet Medyczny w Łodzi
} 


\section{Diagnosis and treatment of basal cell and squamous cell carcinoma and melanoma of the skin recommended by the Oncology Section of the Polish Dermatology Society as well as the Melanoma Academy Section of the Polish Society of Oncological Surgery}

Basal cell carcinoma (BCC) as well as the squamous cell carcinoma (SCC) are the most frequent malignant neoplasms among Caucasian patients. Despite the fact, that they seldom metastasise and are not directly fatal, they constitute a significant clinical issue. Such cancers infiltrate surrounding tissues and destroy the surrounding structures, e.g., bones and cartilages. This results in such structures developing severe defects and significantly reduces the quality of life of the patients. Those with chronic immunosuppresion or a genetic predisposition to develop UV-induced skin cancer are at risk of dying, particularly if the cancer is aggressive. The Oncology Department of the Polish Dermatology Society (Polish: Sekcja Onkologiczna Polskiego Towarzystwa Dermatologicznego — PTD) as well as the Melanoma Academy Department of the Polish Society of Oncological Surgery (Polish: sekcja Akademia Czerniaka Polskiego Towarzystwa Chirurgii Onkologicznej — PTChO), basing on the current European guidelines, American recommendations of the National Comprehensive Cancer Network (revision 1.2015) and interventional reviews of publications elaborated by the Cochrane Skin Group, attempted to systemise the diagnostic and therapeutic procedures and o determine rules for primary and secondary prevention in patients suspected/diagnosed with a basal cell or squamous cell carcinoma. The paper presents recommendations regarding diagnosis and treatment of skin cancers, taking all related benefits and challenges into consideration, as well as recommendations for post treatment patients monitoring.

NOWOTWORY Journal of Oncology 2016; 66, 1: 35-44

Słowa kluczowe: rak podstawnokomórkowy, rak kolczystokomórkowy, rozpoznanie, leczenie

Key words: basal cell carcinoma BCC, squamous cell carcinoma SCC, diagnosis, treatment

\section{Wstęp}

Rak podstawnokomórkowy (BCC - basal cell carcinoma) oraz rak kolczystokomórkowy (SCC - squamous cell carcinoma) są najczęściej występującymi nowotworami złośliwymi u osób rasy kaukaskiej. Pomimo że rzadko prowadzą do powstawania przerzutów i zgonu chorego, to stanowiąjednak bardzo istotny problem kliniczny. Raki te charakteryzują się bowiem naciekaniem okolicznych tkanek i niszczeniem sąsiadujących struktur, takich jak kości i chrząstki, co sprawia, że stają się powodem poważnych defektów estetycznych i znacząco upośledzają jakość życia chorych. Wśród pacjentów z grup wysokiego ryzyka (tzn. osób w trakcie przewlekłej immunosupresji lub z genetyczną predyspozycją do zachorowania na nowotwory skóry indukowane promieniowaniem UV) raki skóry mogą mieć agresywny i prowadzący do śmierci przebieg. Należy również podkreślić, że u chorych, którzy uprzednio chorowali na raka skóry, częściej niż w ogólnej populacji stwierdza się czerniaka [1].

Sekcja Onkologiczna Polskiego Towarzystwa Dermatologicznego (PTD) oraz sekcja Akademia Czerniaka Polskiego Towarzystwa Chirurgii Onkologicznej (PTChO), na podstawie aktualnych wytycznych europejskich, rekomendacji amerykańskich National Comprehensive Cancer Network (wersja 1.2015) oraz interwencyjnych recenzji publikacji opracowanych przez Cochrane Skin Group, podjęła próbę usystematyzowania zasad postępowania diagnostyczno-terapeutycznego oraz ustalenia jednorodnych zasad prewencji pierwotnej i wtórnej u pacjentów z podejrzeniem/ /rozpoznaniem raka podstawnokomórkowego lub kolczy- stokomórkowego. Należy zaznaczyć, że opracowanie nie obejmuje problematyki dotyczącej stanów przednowotworowych (m.in. rogowacenia słonecznego), jak również raków kolczystokomórkowych czy płaskonabłonkowych zlokalizowanych w obrębie narządów płciowych, łożyska paznokci i jamy ustnej.

\section{Epidemiologia}

Raki skóry stanowią 75\% wszystkich rozpoznawanych nowotworów złośliwych [2]. Ryzyko zachorowania na te nowotwory w ciągu życia (u osób rasy kaukaskiej) przekracza $20 \%$. Zachorowalność wykazuje tendencję rosnącą wraz $z$ wiekiem pacjentów (najwięcej zachorowań notuje się w 8. dekadzie życia). W 2011 roku w Polsce zarejestrowano 11439 nowych zachorowań (5408 u mężczyzn i 6031 u kobiet), co odpowiada zachorowalności wynoszącej odpowiednio $7,5 \%$ i 8,3\% [2, 3]. Niestety, w tej grupie nowotworów należy spodziewać się znacznego stopnia niedorejestrowania, wynikającego z niepełnej sprawozdawczości do Krajowego Rejestru Nowotworów.

Zdecydowanie najczęstszym z raków skóry jest rak podstawnokomórkowy, który stanowi ok. $80 \%$ wszystkich raków skóry. Na drugim miejscu znajduje się rak kolczystokomórkowy, stanowiący ok. 15\%-20\% raków skóry [2]. Inne postacie są znacząco rzadsze [4].

\section{Czynniki ryzyka}

Szybko rosnąca zachorowalność na BCC i SCC związana jest m.in. z nadmierną ekspozycją na promieniowanie ultra- 
fioletowe. Głównych przyczyn odpowiadających za coraz częstsze występowanie raków skóry upatruje się w zmianie stylu życia i sposobu ubierania się ,,,modzie” na opaleniznę, migracji ludzi o fototypie I, II i III skóry w regiony świata o dużym nasłonecznieniu, stałych pobytach w rejonach górskich lub niskich szerokościach geograficznych, a także w korzystaniu z lamp emitujących promieniowanie UV (tzw. solariów). Istotnym czynnikiem ryzyka rozwoju BCC i SCC jest również narażenie zawodowe na promieniowanie UV osób wykonujących pracę na zewnątrz i niestosujących żadnej formy fotoprotekcji [5]. W tabeli I przedstawiono czynniki ryzyka rozwoju raka skóry [6].

\section{Diagnostyka}

Rozpoznanie wstępne ustala się na podstawie badania podmiotowego i charakterystycznego dla BCC oraz SCC obrazu klinicznego. W obrębie głowy i szyi zlokalizowanych jest $80 \%$ raków skóry, natomiast pozostałe $20 \%$ występuje na kończynach i tułowiu [3,5]. Warto zaznaczyć, że w drugiej z tych grup stwierdza się także zwiększone ryzyko rozwoju czerniaka.

Raki skóry często charakteryzują się wieloogniskowym rozwojem. Dotyczy to w szczególności chorych po 70. roku życia o znacznym stopniu fotouszkodzenia skóry. Nierzadko u tych chorych stwierdza się nawet kilkanaście ognisk raka podstawnokomórkowego, liczne ogniska rogowacenia słonecznego, jak i ogniska choroby Bowena lub czerniaki. Z tego powodu bardzo istotne jest precyzyjne przeprowadzenie badania podmiotowego i przedmiotowego. Wobec udowodnionej licznymi publikacjami przydatności dermoskopii w diagnostyce wczesnych nowotworów skóry zaleca się, aby tę szybką i nieinwazyjną metodę diagnostyczną traktować jako stały element badania przedmiotowego [7-9]. Szczególnie ważne jest wykonanie badania dermoskopowego w przypadkach nietypowych, wymagających wykluczenia zmian o odmiennej etiologii (diagnostyka różnicowa), ocenie zmian o niewielkim rozmiarze, jak również zróżnicowania ognisk rogowacenia słonecznego z przedinwzyjnym SCC (in situ). Badanie to powinno być również wykorzystywane do oceny rozległości ogniska nowotworu przed planowanym leczeniem, a także do oceny radykalności tego leczenia i monitorowania pacjentów po leczeniu.

Refleksyjna konfokalna mikroskopia skaningowa — jako kolejna nieinwazyjna procedura diagnostyczna — z uwagi na jej bardzo ograniczoną dostępność nadal pozostaje metodą wykorzystywaną głównie w celach naukowych.

W przypadkach niejednoznacznych oraz w celu wyboru metody terapeutycznej nadal,złotym standardem" pozostaje badanie histopatologiczne wycinka zmiany skórnej. Typ histopatologiczny nowotworu oraz stopień zaawansowania, wraz z oceną stanu pacjenta, będą miały decydujące znaczenie przy podejmowaniu dalszych decyzji.
Tabela I. Czynniki ryzyka rozwoju raka skóry [6]

\begin{tabular}{|c|c|c|c|}
\hline \multicolumn{2}{|c|}{ Czynniki ryzyka rozwoju raka skóry } & \multirow[t]{2}{*}{ SCC } & \multirow{2}{*}{$\frac{B C C}{\times}$} \\
\hline 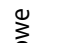 & Kumulacyjna dawka UV & & \\
\hline$\frac{\sqrt[y]{n}}{3}$ & $\begin{array}{l}\text { Intensywne przerywane kąpiele } \\
\text { słoneczne }\end{array}$ & $x$ & \\
\hline$\stackrel{0}{\frac{0}{\omega}}$ & Promieniowanie jonizujące & $x$ & $x$ \\
\hline 产 & Ekspozycja na substancje chemiczne* & $x$ & $(x)$ \\
\hline$N$ & Infekcje HPV & $x$ & \\
\hline \multirow{11}{*}{ 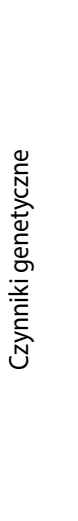 } & Nikotynizm & $x$ & \\
\hline & I fenotyp skóry & $\times$ & $x$ \\
\hline & Skóra pergaminowa i barwnikowa & $x$ & $x$ \\
\hline & Albinizm „oczno-skórny” & $x$ & $(x)$ \\
\hline & Nabłonkowa dysplazja brodawkowata & $x$ & \\
\hline & Pęcherzowe oddzielanie się naskórka & $x$ & \\
\hline & Zespół Fergusona-Smitha & $x$ & \\
\hline & Zespół Muira-Torre’a & $x$ & $(x)$ \\
\hline & Zespół Bazexa & & $x$ \\
\hline & Zespół Rombo & & $x$ \\
\hline & Zespół Gorlina-Goltza & & $x$ \\
\hline \multirow{7}{*}{ 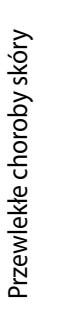 } & Przewlekłe niegojące się owrzodzenia & $x$ & \\
\hline & Długo utrzymujący się: & & \\
\hline & — toczeń rumieniowaty skórny & & \\
\hline & — liszaj płaski (nadżerkowy) & $x$ & \\
\hline & — liszaj twardzinowy & & \\
\hline & Porokeratoza & $x$ & \\
\hline & Znamię łojowe & & $x$ \\
\hline \multirow{2}{*}{ 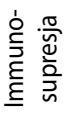 } & Stan po przeszczepie narządu & $x$ & $(x)$ \\
\hline & $\begin{array}{l}\text { Innego rodzaju immunosupresja } \\
\text { np. zespół AIDS, zakażenie HPV }\end{array}$ & $x$ & \\
\hline
\end{tabular}

*Substancje chemiczne: arsen, olej mineralny, smoła węglowa, sadza, iperyt azotowy, aromatyczne związki policykliczne - pochodne bifenylu, 4,4'bipyridyl, psoralen (z UVA) [1, 2, 4-6]

Podejrzenie zmiany inwazyjnej (objawiające się głębokim naciekiem, zajęciem tkanek i struktur położonych poniżej/w sąsiedztwie guza — tj.: mięśni, kości, nerwów, węzłów chłonnych, gałki ocznej) jest wskazaniem do rozszerzenia diagnostyki o badania obrazowe (tomografii komputerowej, rezonansu magnetycznego) $[1,4,5,7,10-12]$.W przypadku stwierdzenia w badaniu przedmiotowym lub w badaniu obrazowym powiększonych regionalnych węzłów chłonnych należy wykonać biopsję cienkoigłową lub pobrać cały węzeł do badania histopatologicznego [1, 4].

Kolejnym etapem jest ocena występowania czynników prognostycznych dotyczących konkretnej zmiany nowotworowej, które decydują o jej przynależności do grupy wysokiego lub niskiego ryzyka (tab. II i III), oraz ocena stopnia zaawansowania według Amerykańskiego Towarzystwa do Walki z Rakiem (AJCC - American Joint Committee on Cancer), rewizja z 2009 roku (tab. IV). 
Tabela II. Ocena ryzyka dla raka kolczystokomórkowego [1, 3-4]

\begin{tabular}{|c|c|c|}
\hline \multicolumn{3}{|c|}{ Czynniki ryzyka nawrotu miejscowego i odległego SCC } \\
\hline Lokalizacja i rozmiar & Zmiana niskiego ryzyka & Zmiana wysokiego ryzyka \\
\hline & Obszar $\mathrm{L}<20 \mathrm{~mm}$ & Obszar L $\geq 20 \mathrm{~mm}$ \\
\hline & Obszar $\mathrm{M}<10 \mathrm{~mm}$ & Obszar $\mathrm{M} \geq 10 \mathrm{~mm}$ \\
\hline & Obszar $\mathrm{H}<6 \mathrm{~mm}$ & Obszar $\mathrm{H} \geq 6 \mathrm{~mm}$ \\
\hline Brzegi zmiany & Dobrze, ostro odgraniczone & Granice nieostre \\
\hline Guz pierwotny/nawrotowy & Pierwotny & Nawrotowy \\
\hline Immunosupresja & Nie & Tak \\
\hline Wcześniejsza radioterapia lub przewlekły proces zapalny w obrębie guza & Nie & Tak \\
\hline Szybki wzrost guza & Nie & Tak \\
\hline Objawy neurologiczne & Nie & Tak \\
\hline Stopień histologicznego zróżnicowania & $\begin{array}{l}\text { Dobrze lub średnio zróżnicowany } \\
\mathrm{G} 1, \mathrm{G} 2\end{array}$ & Nisko zróżnicowany G3 \\
\hline Grubość guza & $<2 \mathrm{~mm}$ & $\geq 2 \mathrm{~mm}$ \\
\hline Naciekanie nerwów oraz naczyń & $\begin{array}{l}\text { I-IIl poziom wg Clarka } \\
\text { Nie }\end{array}$ & $\begin{array}{l}\text { IV-V poziom wg Clarka } \\
\text { Tak }\end{array}$ \\
\hline Typ histopatologiczny & metatypicus & acantholiticus \\
\hline & verrucosus & desmoplasticus \\
\hline & fusiformis & adenoidalis, adenoidosquamousus \\
\hline & mixtus & mucosoadenoidalis \\
\hline & & fusiformis (po radioterapii) \\
\hline
\end{tabular}

Obszar L — tułów i kończyny z wyłączeniem przedniej powierzchni podudzia, rąk, stóp, kostek i paznokci

Obszar M - część środkowa twarzy, policzki, czoło, skóra owłosiona głowy, szyja, przednia powierzchnia podudzia

Obszar H - głowa i szyja z wyłączeniem obszaru M, genitalia, ręce i stopy

Tabela III. Ocena ryzyka dla raka podstawnokomórkowego [1, 3, 4]

\begin{tabular}{|c|c|c|}
\hline \multicolumn{3}{|c|}{ Czynniki ryzyka nawrotu BCC } \\
\hline Lokalizacja i rozmiar & Zmiana niskiego ryzyka & Zmiana wysokiego ryzyka \\
\hline & Obszar $\mathrm{L}<20 \mathrm{~mm}$ & Obszar L $\geq 20 \mathrm{~mm}$ \\
\hline & Obszar $\mathrm{M}<10 \mathrm{~mm}$ & Obszar $\mathrm{M} \geq 10 \mathrm{~mm}$ \\
\hline & Obszar $\mathrm{H}<6 \mathrm{~mm}$ & Obszar $\mathrm{H} \geq 6 \mathrm{~mm}$ \\
\hline Brzegi zmiany & Dobrze, ostro odgraniczone & Granice nieostre \\
\hline Guz pierwotny /nawrotowy & Pierwotny & Nawrotowy \\
\hline Immunosupresja & Nie & Tak \\
\hline Wcześniejsza radioterapia & Nie & Tak \\
\hline \multirow[t]{5}{*}{ Typ histopatologiczny } & - powierzchowny & — bliznowaciejący \\
\hline & - guzkowy & - twardzinopodobny \\
\hline & - fibroepithelioma & - metatypowy \\
\hline & — rogowaciejący & — naciekający \\
\hline & — mieszkowocystowaty & — zmiany mikroguzkowe w jakimkolwiek obszarze guza \\
\hline Naciekanie okołonerwowe & Nie & Tak \\
\hline
\end{tabular}

Obszar L — tułów i kończyny z wyłączeniem przedniej powierzchni podudzia, rąk, stóp, kostek i paznokci

Obszar M - część środkowa twarzy, policzki, czoło, skóra owłosiona głowy, szyja, przednia powierzchnia podudzia

Obszar $\mathrm{H}$ - głowa i szyja z wyłączeniem obszaru M, genitalia, ręce i stopy

Brantsch i wsp. w prospektywnym badaniu trwającym 20 lat (średni czas obserwacji wyniósł 43 miesiące) i obejmującym 615 pacjentów wykazał korelację pomiędzy głębokością naciekania SCC i częstością występowania wznowy miejscowej/rozsiewu. W przypadku gdy głębokość nacie- kania nie przekraczała $2 \mathrm{~mm}$, częstość nawrotów wyniosła $0 \%$. W przypadku naciekania na głębokość od 2,1 $\mathrm{mm}$ do $6 \mathrm{~mm}$ - częstość nawrotów wynosiła 4\%, a gdy naciekanie przekraczało $6 \mathrm{~mm}-16 \%$. Inwazyjność nowotworu korelowała także z oceną głębokości naciekania wg skali 
Tabela IV. Klasyfikacja stopni zaawansowania raka skóry (2009 r.)

\begin{tabular}{ll}
\hline \multicolumn{2}{c}{ Cecha T (zmiana pierwotna)* } \\
\hline Tx & Brak możliwości oceny \\
T0 & Bez cech zmiany pierwotnej \\
Tis & Rak in situ \\
T1 & Nowotwór o największym wymiarze $\leq 2 \mathrm{~cm} \mathrm{z<2} \mathrm{czynnikami} \mathrm{wysokiego} \mathrm{ryzyka}{ }^{\#}$ \\
T2 & Nowotwór o największym wymiarze $>2 \mathrm{~cm}$ \\
& lub \\
T3 & Nowotwór o każdym wymiarze $z \geq 2$ czynnikami wysokiego ryzyka\# \\
T4 & Nowotwór z naciekaniem szkieletu lub okołonerwowe nacieki na podstawę czaszki \\
\hline
\end{tabular}

*Nie dotyczy klinicznej postaci raka kolczystokomórkowego powieki; ${ }^{*}$ czynniki wysokiego ryzyka zmiany pierwotnej (cecha T)

Czynniki wysokiego ryzyka

\begin{tabular}{ll}
\hline Głębokość nacieku zmiany pierwotnej & $>2 \mathrm{~mm}$ \\
Poziom nacieku wg Clarka $\geq \mathrm{IV}$ & Nacieki przestrzeni okołonerwowych \\
Lokalizacja zmiany & Małżowina uszna \\
& Czerwień wargowa \\
Zróżnicowanie & Warga niepokryta włosami \\
\hline
\end{tabular}

Cecha N (regionalne węzły chłonne)

\begin{tabular}{|c|c|}
\hline Nx & Brak możliwości oceny \\
\hline NO & Bez przerzutów do węzłów chłonnych \\
\hline N1 & $\begin{array}{l}\text { Przerzut do pojedynczego węzła chłonnego położonego w spływie po stronie pierwotnej zmiany; wielkość węzła } \leq 3 \mathrm{~cm} \\
\text { w największym wymiarze }\end{array}$ \\
\hline N2 & $\begin{array}{l}\text { Przerzut do pojedynczego węzła chłonnego położonego w spływie po stronie pierwotnej zmiany; wielkość węzła }>3 \mathrm{~cm} \text {, ale }<6 \mathrm{~cm} \text {; } \\
\text { lub do licznych węzłów chłonnych po stronie zmiany pierwotnej, jednak żaden węzeł chłonny nie jest większy niż } 6 \mathrm{~cm} \text {; lub }\end{array}$ \\
\hline & obustronne przerzuty lub przerzuty na pr zeciwną stronę niż zmiana pierwotna, jednak węzły chłonne $<6 \mathrm{~cm}$ \\
\hline $\mathrm{N} 2 \mathrm{a}$ & Przerzut do pojedynczego węzła chłonnego położonego w spływie po stronie pierwotnej zmiany; wielkość węzła $>3 \mathrm{~cm}$, ale $<6 \mathrm{~cm}$ \\
\hline $\mathrm{N} 2 \mathrm{~b}$ & Przerzut do licznych węzłów chłonnych po stronie pierwotnej zmiany, jednak żaden węzeł chłonny nie jest większy niż $6 \mathrm{~cm}$ \\
\hline $\mathrm{N} 2 \mathrm{C}$ & Przerzuty obustronne lub przerzuty na przeciwną stronę niż zmiana pierwotna, jednak węzły chłonne nie większe niż $6 \mathrm{~cm}$ \\
\hline N3 & Przerzut do węzła chłonnego o wielkości > 6 cm w największym wymiarze \\
\hline \multicolumn{2}{|c|}{ Cecha M (przerzuty odległe) } \\
\hline M0 & Bez przerzutów \\
\hline M1 & Obecne przerzuty \\
\hline
\end{tabular}

\begin{tabular}{|c|c|c|c|}
\hline \multicolumn{4}{|c|}{ Stopnie zaawansowania choroby nowotworowej } \\
\hline Stopień 0 & Tis & No & Mo \\
\hline Stopień I & $\mathrm{T} 1$ & No & Mo \\
\hline Stopień II & $\mathrm{T} 2$ & No & Mo \\
\hline \multirow[t]{4}{*}{ Stopień III } & T3 & No & Mo \\
\hline & $\mathrm{T} 1$ & N1 & M0 \\
\hline & $\mathrm{T} 2$ & N1 & MO \\
\hline & T3 & N1 & Mo \\
\hline \multirow[t]{6}{*}{ Stopień IV } & $\mathrm{T} 1$ & N2 & Mo \\
\hline & $\mathrm{T} 2$ & N2 & Mo \\
\hline & T3 & N2 & Mo \\
\hline & T każdy & N3 & Mo \\
\hline & $\mathrm{T} 4$ & N każdy & Mo \\
\hline & T każdy & N każdy & M1 \\
\hline \multicolumn{4}{|c|}{ Histologiczne stopnie złośliwości (G) } \\
\hline Gx & Nie może być oceniony & & \\
\hline G1 & Dobrze zróżnicowany & & \\
\hline G2 & Średnio zróżnicowany & & \\
\hline G3 & Źle zróżnicowany & & \\
\hline G4 & Niezróżnicowany & & \\
\hline
\end{tabular}


Clarka. Wymienione czynniki mają istotne znaczenie rokownicze.

\section{Zalecenia diagnostyczno-terapeutyczne}

$\mathrm{U}$ chorych na raki skóry nadrzędnym celem postępowania jest doszczętne usunięcie tkanek nowotworowych, dlatego w pierwszej kolejności należy wybierać metody odznaczające się największą doszczętnością i jednocześnie najmniejszym ryzykiem niepowodzenia miejscowego.

Wybór terapii powinien być warunkowany:

- oceną kliniczną, liczebnością i rozmiarami ognisk raków skóry,

- typem histopatologicznym,

- stopniem inwazyjności nowotworu, ryzykiem jego nawrotu miejscowego i odległego (ryzykiem odległych przerzutów oraz wznowy miejscowej),

- zachowaniem funkcji narządu/części ciała i ostatecznego efektu estetycznego okolicy poddanej leczeniu,

- skutecznością terapii, ocenianą jako odsetek nawrotów w ciągu 4-6 miesięcy oraz 3-5 lat (weryfikowaną badaniem przedmiotowym, dermoskopowym, histopatologicznym),

- tolerancją leczenia (dolegliwości bólowe, czas leczenia, działania niepożądane, ryzyko powikłań),

- dostępnością danej metody terapeutycznej,

- stanem immunokompetencji pacjenta,

- indywidualnymi preferencjami pacjenta.

Na rycinie 1 przedstawiono zalecane postępowanie diagnostyczno-terapeutyczne w przypadku podejrzenia raka skóry.

Postępowanie chirurgiczne często jest najszybszą oraz najskuteczniejszą metodą prowadzącą do wyleczenia, jednak wybierając strategię działania, należy uwzględnić m.in. zaawansowany wiek chorego i liczne obciążenia internistyczne, aspekt psychologiczny oraz estetyczny. Dlatego w niektórych przypadkach dopuszczalne jest zastosowanie alternatywnych — wobec wycięcia - metod leczenia (w szczególności w przypadku raków o niskim ryzyku nawrotu).

Należy podkreślić, iż nadal brakuje dobrych jakościowo, porównawczych badań dotyczących różnych metod leczenia raków skóry. Większość publikacji dotyczy zmian w lokalizacji, która wiąże się z niskim ryzykiem nawrotów/ /inwazyjności. Leczenie chirurgiczne w przypadku raka skóry (z wyjątkiem zmian nieoperacyjnych) nadal pozostaje „złotym standardem" $[1,4,5,7]$.

\section{Leczenie raka skóry - leczenie podstawowe Wycięcie z ocenq histopatologiczną marginesów chirurgicznych}

Jest to najczęściej stosowana metoda leczenia raka skóry (zarówno w przypadku dużego, jak i małego ryzyka nawrotu).
Zaleca się zachowanie marginesu operacyjnego wynoszącego co najmniej $4 \mathrm{~mm}$ w przypadku BCC i $6 \mathrm{~mm}$ w przypadku SCC. W odniesieniu do raka należącego do grupy wysokiego ryzyka zaleca się śródoperacyjną kontrolę doszczętności (chirurgia mikrograficzna Mohsa). Jeżeli nie ma takiej możliwości, rekomenduje się szersze marginesy wycięcia - $10 \mathrm{~mm}$.W przypadku gdy tak rozległe marginesy niezmienionej nowotworowo skóry wpływają negatywnie na efekt kosmetyczny, można rozważyć wycięcie radykalne z mniejszym marginesem (R0 - margines wolny od komórek nowotworowych w badaniu histopatologicznym), gdyż taki margines wymagany jest w przypadku operacji metodą chirurgii mikrograficznej Mosha. Chirurgia mikrograficzna Mohsa polega na warstwowym wycinaniu guza z śródoperacyjną oceną zamrożonych skrawków pochodzących z brzegów oraz dna loży po guzie. Poszczególne wycinki są szczegółowo oznakowywane tak, aby w następstwie uzyskanych wyników poszerzyć wyłącznie te marginesy operacyjne, w których stwierdzono komórki nowotworowe. Procedura ta pozwala na radykalne wycięcie guza z możliwie największym zaoszczędzeniem tkanek zdrowych $[1,4,5,7,10]$.

\section{Radioterapia}

Radioterapia samodzielna może być stosowana w przypadku BCC iSCC (zarówno o niskim, jak i wysokim ryzyku nawrotu) u pacjentów powyżej 60 roku życia jako alternatywa dla pierwotnego wycięcia zmiany. W szczególności metoda ta znajduje zastosowanie u pacjentów z chorobą Bowena o dużych rozmiarach lub w przypadku wieloogniskowości, a także u osób, które nie wyraziły zgody na wycięcie.

Radioterapię uzupełniającą stosuje się w przypadkach zaawansowanych lokoregionalnie raków skóry (w szczególności gdy stwierdza się naciekanie okołonerwowe), po limfadenektomii z powodu przerzutów SCC do regionalnych węzłów chłonnych, a także wówczas, gdy operacja była niedoszczętna i nie ma możliwości radykalizacji chirurgicznej. Zaleca się tę metodę także w przypadku, gdy wycięcie raka skóry przeprowadzono metodą mikrograficzną Mohsa.

Wadą radioterapii jest występowanie wczesnych i odległych powikłań, które mają tendencję do nasilania się w miarę upływu czasu. Należą do nich m.in.: martwica skóry, popromienne zapalenie skóry i błony śluzowej, zmiany pigmentacyjne (trwałe przebarwienia skóry).

Przeciwwskazaniem do zastosowania radioterapii są:

- czynniki genetyczne predysponujące do zespołów związanych z rakiem podstawnokomórkowym,

- xeroderma pigmentosum,

- wiek pacjenta poniżej 60 lat (przeciwwskazanie względne),

- rak podstawnokomórkowy twardzinopodobny,

- występowanie zmian w lokalizacji: małżowina uszna, ręce, stopy, kończyny oraz okolica narządów płciowych. 


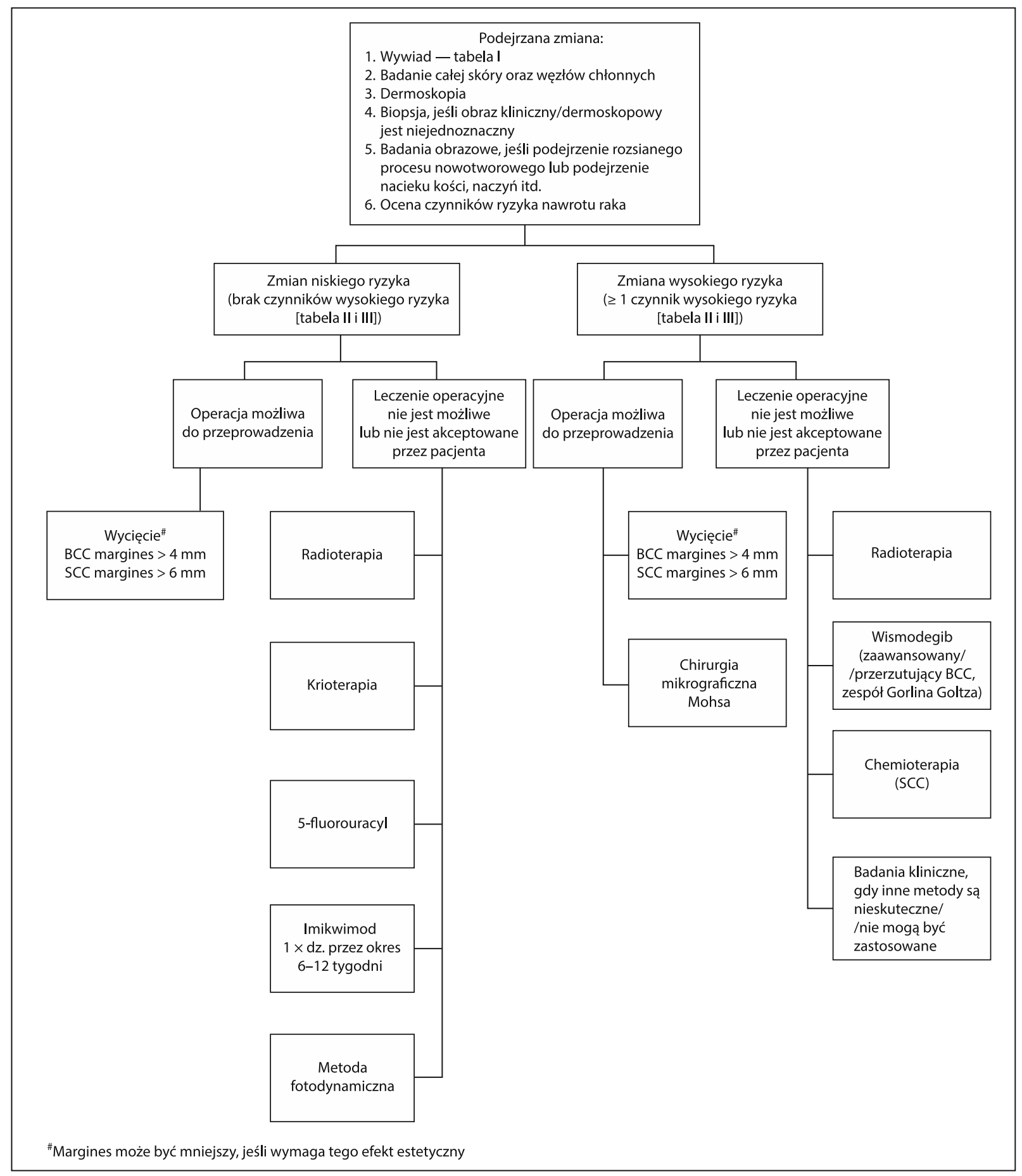

Rycina 1. Zalecane postępowanie diagnostyczno-terapeutyczne w przypadku podejrzenia raka skóry

\section{Chemioterapia}

Dla pacjentów z SCC w fazie rozsiewu nie ma danych, które potwierdzałyby jednoznacznie na skuteczność chemioterapii z cisplatyną w monoterapii lub w kombinacji z5-fluorouracylem, interferonem, kwasem cis-retinowym. Dostępne są doniesienia o potencjalnej skuteczności inhibitorów EGFR (cetuksymab, gefitynib), które jednak wymagają przeprowadzenia dalszych badań klinicznych [1, 4, 5-7, 10, 11, 13].

\section{Inhibitory ścieżki Hedgehog}

U pacjentów z genetyczną predyspozycją do rozwoju mnogich BCC (zespół Gorlina i Goltza), u pacjentów z BCC $w$ fazie rozsiewu, a także u pacjentów z regionalnie zaawansowanym BCC, którzy wyczerpali możliwości leczenia chirurgicznego i radioterapii, należy rozważyć leczenie wismodegibem (drobnocząsteczkowym inhibitorem szlaku Hedgehog). Lek ten (w dawce 150 mg/d) wydłużał czas do 
progresji choroby, z obiektywnymi odpowiedziami wynoszącymi od 30\% do 60\%. Najczęstsze zdarzenia niepożądane podczas terapii wismodegibem ( $u>30 \%$ chorych) obejmują skurcze mięśni, łysienie, zaburzenia smaku, zmniejszenie masy ciała, zmęczenie i nudności [14-16]. Kolejnym inhibitorem szlaku Hedgehog, który uzyskał już rejestrację w Stanach Zjednoczonych, jest sonidegib [14-17].

\section{Badania kliniczne}

W przypadku BCC lub SCC o zaawansowaniu regionalnym lub systemowym, u których wyczerpano możliwości terapeutyczne, należy rozważyć włączenie pacjentów do udziału w badaniach klinicznych [1, 4, 14, 15, 17, 18].

Leczenie raków skóry: napromienianiem i/lub z zastosowaniem chemioterapii i leczenia celowanego powinno odbywać się w wysokoprofilowych ośrodkach.

\section{Leczenie raka skóry — metody powierzchowne}

W przypadku BCC i SCC charakteryzującego się małym ryzykiem nawrotu można rozważyć zastosowanie powierzchownych metod leczenia. Ze względu na gorszą skuteczność tych metod należy ich użycie ograniczyć do pacjentów, u których istnieją przeciwwskazania do metod podstawowych (przede wszystkim chirurgicznych). Leczenie powierzchowne można również rozważyć w odniesieniu do pacjentów z powierzchownym rakiem podstawnokomórkowym o niskim ryzyku nawrotu, jeśli spodziewane efekty estetyczne będą lepsze.

\section{5-fluorouracyl}

Lek ma zastosowanie w leczeniu rogowacenia słonecznego, raka podstawnokomórkowego szerzącego się powierzchownie i raka kolczystokomórkowego in situ. Preparat stosuje się $2 \times$ dziennie przez okres 4, 6 lub 11 tygodni w przypadku powierzchownej postaci BCC (całkowitą odpowiedź uzyskuje się u 90\% chorych). W przypadku rogowacenia słonecznego preparat stosuje się średnio 2-4 tygodnie (całkowita odpowiedź w 82\% zmian skórnych) $[1,4,5-7,10,11,19]$.

\section{Imikwimod (5\%)}

Lek ma zastosowanie w leczeniu rogowacenia słonecznego, SCC in situ/choroby Bowena oraz nieinwazyjnych postaci BCC szerzącego się powierzchownie. Krem stosuje się obecnie dłużej i aplikuje częściej (badania wykazały, że wydłużenie czasu leczenia z 6 do 12 tygodni i aplikacje 1-2 $\times$ dziennie), skutkują mniejszym ryzykiem niepowodzenia leczenia). Zastosowanie leku w okluzji w przypadku powierzchownej i guzkowej postaci BCC do $2 \mathrm{~cm}$ średnicy wiąże się z porównywalną skutecznością. Dla przykładu: 5 lat bez objawów choroby obserwowano u $84 \%$ chorych na postać powierzchowną BCC. W przypadku pacjentów immunokompetentnych można stosować wyłącznie krem, zaś w przypadku pacjentów poddanych immunosupresji leczenie imikwimodem powinno się kojarzyć z kriochirurgią, mikrochirurgią Mohsa, metodą fotodynamiczną [1, 4, 5-7, $10,11,19]$.

\section{Metoda fotodynamiczna}

Metoda ta w leczeniu raków skóry rekomendowana jest do leczenia BCC szerzącego się powierzchownie i guzkowego oraz w leczeniu SCC in situ/choroby Bowena i rogowacenia słonecznego. Dla potrzeb tej metody stosuje się kwas delta-aminolewulinowy (ALA) oraz aminolewulinian metylu (MAL). Źródłami światła mogą być lampy oraz lasery. $\mathrm{W}$ randomizowanym wieloośrodkowym badaniu oceniano efektywność leczenia 601 ognisk powierzchownie szerzącego się BCC. Po leczeniu remisję nowotworu stwierdzono u 72,8\% leczonych MAL-PDT ( 2 sesje w odstępie tygodnia) w porównaniu z $83,4 \%$ pacjentów leczonych imikwimodem ( $5 \times$ w tygodniu przez 6 tygodni) oraz $80,1 \%$ leczonych 5 -fluorouracylem ( $2 \times$ dziennie przez 4 tygodnie) $[1,4,20,21]$.

W innych analizach wykazano skuteczność metody fotodynamicznej (definiowaną jako odsetek całkowitych odpowiedzi po 3 miesiącach i 2 latach) w leczeniu rogowacenia słonecznego (odpowiednio 93\%, 69\%), choroby Bowena $(93 \%, 68 \%)$, powierzchownej postaci BCC $(93 \%$, $85 \%)$ i guzkowej postaci BCC $(75 \%-82 \%, 77 \%$ po 60 miesiącach) $[20,21]$.

W 2013 r. opublikowano konsensus leczenia metodą fotodynamiczną ognisk BCC u pacjentów z zespołem Gorlina i Goltza. Na podstawie analizy dziewięciu prac przeglądowych podsumowujących wyniki uzyskane u 83 chorych uznano przydatność metody fotodynamicznej jako bezpiecznej i skutecznej w leczeniu BCC szerzących się powierzchownie i BCC guzkowych o głębokości nacieku poniżej $2 \mathrm{~mm}$. Autorzy konsensusu zalecali, aby częstość wizyt kontrolnych była uzależniona od liczby ognisk BCC, częstości nawrotów oraz lokalizacji zmian. Jako istotną zaletę terapii fotodynamicznej podkreślono możliwość równoczesnego leczenia wielu zmian [22].

Ocena skuteczności leczenia miejscowego choroby Bowena na podstawie analizy randomizowanych kontrolowanych badań oceniających skuteczność leczenia po 12 miesiącach obserwacji została opublikowana w 2013 r. Wskazano na brak dobrych jakościowo badań. Dostępne publikacje pozwoliły na wykazanie wyższej skuteczności leczenia MAL-PDT w porównaniu z krioterapią i porównywalną skuteczność w porównaniu z 5-FU oraz podobną skuteczność 5-FU i krioterapii [11, 20].

Z kolei w 2014 r. opublikowano metaanalizę dotyczącą skuteczności leczenia rogowacenia słonecznego, zlokalizowanego na twarzy i/lub skórze głowy, metodą MAL-PDT w porównaniu $z$ innymi procedurami. Po 3 miesiącach od 
zakończenia terapii skuteczność PDT była o14\% wyższa niż krioterapia [23].

Przegląd systematyczny z 2012 r. badań oceniających skuteczność leczenia miejscowego ognisk rogowacenia słonecznego po 3 miesiącach i 2 latach obserwacji wykazał skuteczność wszystkich badanych metod, z zaznaczeniem, iż najlepsze efekty estetyczne osiągano przy zastosowaniu metody PDT i imikwimodu [20]. Metodę fotodynamiczną zalecano na niewielkie obszary gdyż wykazywała wyższą niż krioterapia skuteczność. Z kolei leczenie miejscowe (imikwimod, 5FU, 3\% diklofenac, ingenol mebutate) zalecano na rozległe obszary skóry, wykazując ich porównywalną skuteczność [13, 18, 23].

\section{Krioterapia}

Krioterapia to technika prowadząca do martwicy komórek guza poprzez obniżenie temperatury tkanek do temp. od $-50^{\circ}$ do $-60^{\circ} \mathrm{C}$. Ma ona zastosowanie w leczeniu postaci powierzchownych raków skóry o niskim ryzyku nawrotu i rozmiarach do $2 \mathrm{~cm}$, a także ognisk rogowacenia słonecznego. Nie zaleca się stosowania w zmianach guzkowych. Zróżnicowanie stosowanych technik krioterapii powoduje, że de facto nie da się porównywać skuteczności tej metody przedstawianej w różnych badaniach $[1,4,7]$.

\section{Komentarz}

Z uwagi na brak wiarygodnych dowodów naukowych opartych na randomizowanych badaniach klinicznych, które by wykazywały skuteczność leczenia raków skóry metodą łyżeczkowania i elektrodestrukcji, odmiennie w stosunku do zaleceń europejskich i NCCN - Sekcja Onkologiczna PTD oraz sekcja Akademia Czerniaka PTChO nie rekomendują stosowania tej metody.

Z tych samych powodów Sekcja Onkologiczna PTD i sekcja Akademia Czerniaka PTChO nie zalecają stosowania innych metod destrukcji tkanki nowotworowej, przy zastosowaniu: laseroterapii, dermabrazji i peelingu chemicznego (kwasem trójchlorooctowym), które uniemożliwiają kontrolę doszczętności leczenia.

Nieliczne randomizowane badania oceniające skuteczność leczenia metodą doogniskowych iniekcji interferonu w BCC, mimo iż wykazywały pewną efektywność w leczeniu powierzchownych i guzkowych BCC o niewielkich rozmiarach, wiązały się z wysokim odsetkiem (około $30 \%$ ) wczesnych niepowodzeń i częstymi działaniami niepożądanymi. Wobec powyższego Sekcja Onkologiczna PTD i sekcja Akademia Czerniaka PTChO nie rekomendują stosowania tej metody terapeutycznej[1, 2, 4-7, 10, 11].

\section{Obserwacja po zakończonym leczeniu onkologicznym}

Konieczność ścisłego monitorowania chorych na raki skóry wynika m.in. z następujących przesłanek:
— u 30\%-50\% pacjentów, którzy przebyli raka skóry, w ciągu 5 lat rozwinie się kolejne ognisko podobnego nowotworu,

- 70\%-80\% nawrotów SCC ujawnia się w ciągu pierwszych 2 lat kontroli,

- osoby, który zachorowały na raka skóry, charakteryzują się 10-krotnie większym ryzykiem rozwoju raka skóry w porównaniu z populacją ogólną,

- pacjenci, którzy chorowali na raka skóry, odznaczają się większym ryzykiem wystąpienia czerniaka skóry,

- pacjenci w trakcie przewlekłej immunosupresji wyróżniają się wysokim ryzykiem rozwoju inwazyjnych postaci SCC.

Każde podejrzenie wznowy raka skóry powinno być potwierdzone badaniem histopatologicznym. Badanie dermoskopowe niejednokrotnie umożliwia precyzyjne określenie miejsca pobrania biopsji oraz rozpoznanie wznowy we wcześniejszym stadium [10,11].

W przypadku stwierdzenia powiększonych węzłów chłonnych regionalnych należy wykonać biopsję cienkoigłową (rzadziej pobrać cały węzeł do badania histopatologicznego) oraz przeprowadzić badania obrazowe (TK, MRI) w celu oceny zaawansowania choroby $[1,4,5,7]$.

Zasady obserwacji po leczeniu:

A. BCC lub SCC

- całoroczna fotoprotekcja SPF 30-50+,

- samokontrola pacjenta raz w miesiącu,

- badanie dermatologiczne i dermoskopowe skóry całego ciała co 4-6 miesięcy przez 5 lat, następnie co 6-12 miesięcy do końca życia.

B. BCC lub SCC zaawansowany regionalnie/w stadium rozsiewu

- całoroczna fotoprotekcja SPF 30-50+,

- samokontrola pacjenta raz w miesiącu,

- badanie dermatologiczne i dermoskopowe skóry całego ciała: co 1-3 miesiące przez pierwszy rok, co 2-4 miesiące w drugim roku, co 4-6 miesięcy w 3 roku, następnie co 6-12 miesięcy do końca życia,

- opieka wielospecjalistyczna (m.in.: dermatologiczna, onkologiczna, radioterapeutyczna, neurologiczna, okulistyczna).

Nadzór nad pacjentami po transplantacji narządów

w trakcie przewlekłej immunosupresji:

- całoroczna fotoprotekcja SPF 30-50+,

- samokontrola pacjenta raz w miesiącu,

- badanie dermatologiczne i dermoskopowe skóry całego ciała: co 6-12 miesięcy do końca życia,

- w przypadku stwierdzenia raka skóry zaleca się kontrole co 3-6 miesięcy do końca życia. 
Nadzór nad pacjentami z genetycznie uwarunkowana

predyspozycja do rozwoju raka skóry:

- całoroczna fotoprotekcja SPF 30-50+,

- samokontrola pacjenta raz w miesiącu,

- badanie dermatologiczne i dermoskopowe skóry całego ciała: co 3-6 miesięcy do końca życia,

- u pacjentów z xeroderma pigmentosum rozważenie odwrócenia rytmu dobowego oraz bezwzględne unikanie narażenia na promieniowanie UV, IR, X podczas pracy zawodowej.

\section{Zapobieganie zachorowaniu na raka skóry Prewencja pierwotna}

- ścisły nadzór dermatologiczny nad pacjentami z genetyczną predyspozycją do zachorowania na raka skóry indukowaną przez promieniowanie UV oraz nad osobami w trakcie przewlekłej immunosupresji,

- edukacja społeczeństwa na temat właściwego stosowania fotoprotekcji oraz możliwości wczesnego wykrywania nowotworów skóry [22, 24].

\section{Prewencja wtórna}

- edukacja pacjenta na temat właściwego stosowania fotoprotekcji,

- edukacja pacjenta na temat objawów nowotworów skóry i konieczności wykonywania samobadania,

- regularne dermatologiczne wizyty monitorujące, połączone z badaniem dermoskopowym według ustalonego schematu [8, 9, 24],

- u pacjentów w trakcie przewlekłej immunosupresji, u których stwierdza się występowania objawów rogowacenia słonecznego i/lub NMSC, rozważenie modyfikacji leczenia poprzez redukcję dawek leków z grupy inhibitorów kalcyneuryny i/lub antymetabolicznych na korzyść leków z grupy mTOR [23].

\section{Prof. dr hab. n. med. Witold Owczarek}

Wojskowy Instytut Medyczny

Centralny Szpital Kliniczny MON w Warszawie

ul. Szaserów 128, 04-141 Warszawa

\section{Piśmiennictwo}

1. National Comprehensive Cancer Network Clinical Practice Guidelines in Oncology. Basal Cell Skin Cancer and Squamous Cell Skin CancerVersion 1.2015.

2. Krajowy Rejestr Nowotworów www.onkologia.org.pl.

3. Rutkowski P, Jassem J, Krzakowski M. Złośliwe nowotwory skóry. Gdańsk: Via Medica, 2014.

4. Trakatelli M, Morton C, Nagore E i wsp. Update of the European guidelines for basal cell carcinoma management. Eur J Dermatol 2014; 24: 312-329.

5. Bonerandi JJ, Beauvillain C, Caquant Li wsp. Guidelines for the diagnosis and treatment of cutaneous squamous cell carcinoma and precursor lesions. JEADV 2011; 25 Suppl. 5: 1-51.

6. Nawrocka A, Owczarek W. Zasady diagnostyki u pacjentów z nowotworem skóry. Chir po Dypl 2014 sierpień.

7. Clark CM, Furniss M, Mackay-Wiggan JM. Basal cell carcinoma: an evidence-based treatment update. Am J Clin Dermatol 2014; 15: 197-216.

8. Marghoob AM, Malvehy J, Braun RP (red.). Atlas of dermoscopy. Informa Healthcare, 2012.

9. Argenziano G, Zalaudek I, Giacomel J. Preface. Dermoscopy. Dermatol Clin 2013: 31: XIII-XIV.

10. Bath-Hextall FJ, Perkins W, Bong J, Williams HC. Interventions for basal cell carcinoma of the skin. Cochrane Database Syst Rev 2007; 24: CD003412.

11. Bath-Hextall FJ, Matin RN, Wilkinson D i wsp. Interventions for cutaneous Bowen's disease. Cochrane Database Syst Rev 2013; 24; 6:CD007281. doi: 10.1002/14651858.CD007281.pub2.

12. Bolognia JL, Jorizzo JL, Schaffer JV. Dermatology. Elsevier Saunders 2012

13. Berking C, Hauschild A, Kölbl O i wsp. Basal cell carcinoma-treatments for the commonest skin cancer. Dtsch Arztebl Inter 2014; 111: 389-395.

14. Peris K, Licitra L, Ascierto PA i wsp. Identifying locally advanced basal cell carcinoma eligible for treatment with vismodegib: an expert panel consensus. Future Oncol $2015 ; 11: 703-712$.

15. Proctor $A E$, Thompson LA, O'Bryant CL. Vismodegib: an inhibitor of the Hedgehog signaling pathway in the treatment of basal cell carcinoma. Ann Pharmacother 2014; 48: 99-106.

16. Dreno B, Basset-Seguin N, Caro I i wsp. Clinical benefit assessment of vismodegib therapy in patients with advanced basal cell carcinoma. Oncologist 2014; 19: 790-796.

17. Erdem GU, Sendur MA, Ozdemir NY i wsp. A comprehensive review of the role of the hedgehog pathway and vismodegib in the management of basal cell carcinoma. Curr Med Res Opin 2015; 31: 743-756.

18. Sekulic A, Migden MR, Oro AE i wsp. Efficacy and safety of vismodegib in advanced basal-cell carcinoma. N Eng J Med 2012; 366: 2171-2179.

19. McGillis ST, Fein H. Topical treatment strategies for non-melanoma skin cancer and precursor lesions. Semin Cutan Med Surg 2004; 23:174-183.

20. Arits AH, Mosterd K, Essers BA i wsp. Photodynamic therapy versus topical imiquimod versus topical fluorouracil for treatment of superficial basal-cell carcinoma: a single blind, non-inferiority, randomised controlled trial. Lancet Oncol 2013; 14: 647-654.

21. Lehmann P. Methyl aminolaevulinate-photodynamic therapy: a review of clinical trials in the treatment of actinic keratoses and nonmelanoma skin cancer. Br J Dermatol 2007; 156: 793-801.

22. Basset-Seguin N, Bissonnette R, Girard C i wsp. Consensus recommendations for the treatment of basal cell carcinomas in Gorlin syndrome with topical methylaminolaevulinate-photodynamic therapy. JEADV 2014; 28: 626-632.

23. Gupta AK, Paquet $M$, Villanueva $E$, Brintnell W. Interventions for actinic keratoses. Cochrane Database Syst Rev 2012; 12: CD004415. doi: 10.1002/14651858.CD004415.pub2.

24. Choudhury K, Volkmer B, Greinert R i wsp. Effectiveness of skin cancer screening programmes. Br J Dermatol 2012; 167 Suppl 2: 94-98. 